\title{
Discrepant toxoplasma latex agglutination test results
}

\author{
R E HOLLIMAN, JULIE JOHNSON, KIM DUFFY, LINDA NEW The Public Health \\ Laboratory Service Toxoplasma Reference Laboratory, St George's Hospital, London
}

SUMMARY The analysis of 4450 toxoplasma serology results showed that $59(1 \cdot 3 \%)$ latex agglutination reactions were not confirmed in the dye test. These discrepant results were associated with an unspecified IgM antibody but not associated with kit batch variation, inactivation of sera, concurrent cytomegalovirus infection, or the presence of hepatitis B virus " $e$ " antigen.

The latex agglutination test is useful as a screen for toxoplasma infection but false positive reactions do occur. Patients at risk of severe toxoplasmosis should be investigated by additional tests.

Diagnosis of toxoplasma infection entails testing for specific antibody in the patient's serum. The dye test of Sabin and Feldman remains the established reference assay ${ }^{1}$ but is rarely used outside reference centres. Increased awareness of severe toxoplasma infection in immunocompromised groups has confirmed the need for a serological screening test suitable for use in routine laboratories. One such assay is the latex agglutination test. Workers in Cambridge have drawn attention to potentially misleading results from the latex agglutination test when used to test sera from heart transplant recipients. ${ }^{2}$ The Public Health Laboratory Service Toxoplasma Reference Laboratory at St George's Hospital, London, provides a service to client laboratories in London and south east England. In view of the large numbers of tests performed and routine use of the latex agglutination test, we decided to investigate apparently discrepant latex agglutination test results recorded in our laboratory.

\section{Material and methods}

The results of toxoplasma antibody tests recorded over six months were reviewed. Possible discrepant latex agglutination test results were defined as samples with a dye test titre of $<16$ and latex agglutination titre of $\geqslant 64$. Of such serum samples, those with adequate stored volume were selected for investigation. The number of discrepant latex agglutination test results was recorded in relation to the total numbers of tests performed and the manufacturer's batch number of kit used.

Statistical analysis was performed using the $\chi^{2}$ test.

Accepted for publication 6 October 1988
TOXOPLASMA LATEX AGGLUTINATION TEST (Toxoreagent, Eiken Chemical Company, Japan) This was performed according to the manufacturer's instructions. Each serum sample was tested in duplicate using kits of different batch numbers. The latex agglutination test was repeated after adding an equal volume of 2-mercaptoethanol to an aliquot of test serum to remove IgM. When sufficient serum was available, the assay was also repeated following absorption of the test serum with $T$ gondii, and after dilution of sera in bovine serum albumin (BSA).

\section{ABSOR PTION OF SERA}

An aliquot of $50 \mu \mathrm{l}$ of each serum was incubated with $10^{8} \mathrm{RH}$ strain $T$ gondii in $350 \mu$ of phosphate buffered saline (PBS) at $37^{\circ} \mathrm{C}$ for 30 minutes and then overnight at $4^{\circ} \mathrm{C}$. The parasites were removed by centrifugation at 3000 rpm for 10 minutes. Sera from cases of known toxoplasmosis and samples found to be negative by all toxoplasma tests were used as controls. Aliquots of sera were taken for assay by latex agglutination test following repeated absorption against toxoplasma trophozoites.

\section{DILUTION OF SERA IN BSA}

A $50 \mu \mathrm{l}$ aliquot of test serum was mixed with a $350 \mu \mathrm{l}$ volume of $10 \%$ BSA. Positive and negative control sera were diluted in a similar way. All samples were then assayed by latex agglutination test.

\section{LATEX AGGLUTINATION}

Equal volumes of serum and a suspension of uncoated latex particles were mixed on a dark tile. Agglutination of the latex particles was determined by inspection. 
HEAT INACTIVATION ASSAY

Twelve sera, which had given negative results when tested by latex agglutination test and dye test, were placed in a water bath at $56^{\circ} \mathrm{C}$. These sera were inactivated for three hours with aliquots removed at 30 minute intervals. Each aliquot was assayed by latex agglutination test.

\section{OTHER TOXOPLASMA TESTS}

The dye test was performed in flat-bottomed microtitre plates and read using an inverted microscope. ${ }^{3}$ The direct agglutination test was used as directed by the manufacturers (Toxo-Screen DA bioMérieux, France). Toxoplasma specific IgM was measured by a double antibody sandwich ELISA ${ }^{4}$ and an immunosorbent agglutination assay (ToxoISAGA, bioMérieux, France).

Sera were tested for the presence of rheumatoid factor using the RA $80 \mathrm{kit}$, according to the manufacturer's instructions (Eiken Chemical Company, Japan). Assays for cytomegalovirus (CMV) and Epstein Barr Virus (EBV) specific antibodies and hepatitis $B$ virus " $e$ " antigen were performed in the department of virology, St George's Hospital Medical School, London. Testing for CMV specific IgM was performed by ELISA $^{5}$ and an immunofluorescence antibody assay. ${ }^{6}$ Tests for antinuclear factor were carried out at the Department of Immunology, St Helier Hospital, Carshalton, Surrey.

\section{Results}

Toxoplasma serological test results for 4450 samples were analysed: 59 discrepant latex results were recorded. Latex agglutination test kits from four different manufacturers' batches were used and discrepant
Table 1 Discrepant latex agglutination test results obtained from different kit batches

\begin{tabular}{|c|c|c|c|}
\hline $\begin{array}{l}\text { Manufacturer's } \\
\text { kit batch No }\end{array}$ & $\begin{array}{l}\text { Total No of } \\
\text { sera tested }\end{array}$ & $\begin{array}{l}\text { Discrepant latex } \\
\text { agglutination test } \\
\text { results }(L A T \geqslant 64, \\
D T<16)\end{array}$ & $\begin{array}{l}\text { Percentage of } \\
\text { discrepant } \\
\text { results }\end{array}$ \\
\hline $\begin{array}{l}75010 \\
77016 \\
78019 \\
7 \times 025\end{array}$ & $\begin{array}{r}766 \\
622 \\
2093 \\
969\end{array}$ & $\begin{array}{l}15 \\
15 \\
19 \\
10\end{array}$ & $\begin{array}{l}2.0 \\
2.4 \\
0.9 \\
1.0\end{array}$ \\
\hline Total & 4450 & 59 & $1 \cdot 3$ \\
\hline
\end{tabular}

LAT $=$ latex agglutination test DT $=$ dye test.

results from each batch are shown in table 1 . There was no significant difference between the numbers of discrepant results derived from individual latex agglutination test kit batches.

Two serum samples, both fetal, gave a dye test titre of $>64$ and a latex agglutination test titre of $<16$, but there was insufficient stored serum to permit further investigation. Of the 59 sera producing discrepant latex results, 18 were of sufficient volume to permit detailed examination. Sixteen samples were found to give a dye test titre of $<4$ on repeated testing while the remaining two sera were reactive at a titre of only 4 (2 IU). Latex agglutination test titres were found to be comparable when repeated using a kit from a different batch number. Seventeen of the 18 samples failed to produce a direct agglutination reaction and no sample had detectable toxoplasma specific IgM. Treatment with mercaptoethanol abolished latex agglutination test titres in all sera except that of case 5. Toxoplasma antibody titres measured by each assay are shown in table 2, together with a brief clinical summary of each case. The results of latex agglutination test assays performed on sera diluted in BSA or after repeated

Table 2 Toxoplasma antibody titres

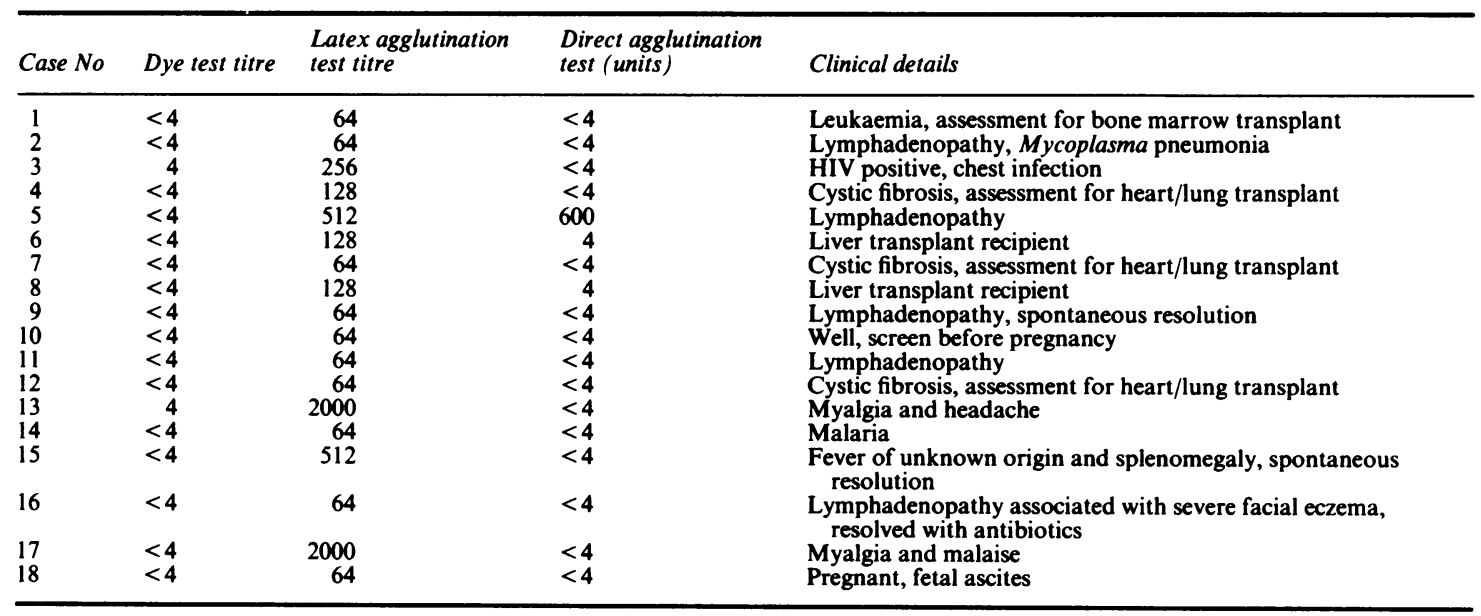


Table 3 Latex agglutination test results

\begin{tabular}{|c|c|c|c|c|c|c|}
\hline \multirow[b]{2}{*}{ Case No } & \multirow{2}{*}{$\begin{array}{l}\text { Latex agglutination } \\
\text { test }(L A T) \text { titre }\end{array}$} & \multirow{2}{*}{$\begin{array}{l}\text { After mercaptoethanol } \\
\text { treatment }\end{array}$} & \multirow{2}{*}{$\begin{array}{l}\text { After dilution in } \\
\text { BSA }\end{array}$} & \multicolumn{3}{|c|}{ After absorption } \\
\hline & & & & (1) & (2) & (3) \\
\hline 1 & 64 & $<8$ & - & 64 & 32 & 32 \\
\hline 2 & 64 & $<8$ & 8 & 64 & 16 & 16 \\
\hline 3 & 256 & $<8$ & 16 & 256 & 128 & 128 \\
\hline 4 & 128 & $<8$ & - & 16 & 16 & 16 \\
\hline 5 & 512 & 512 & 512 & 16 & $<8$ & $<8$ \\
\hline 6 & 128 & $<8$ & 64 & 32 & 32 & 32 \\
\hline 7 & 64 & $<8$ & 16 & 64 & 32 & 32 \\
\hline 8 & 128 & $<8$ & 64 & 32 & 32 & 32 \\
\hline 9 & 64 & $<8$ & $<8$ & 32 & 8 & $<8$ \\
\hline 10 & 64 & $<8$ & - & 32 & 16 & 16 \\
\hline 11 & 64 & $<8$ & $<8$ & 16 & $<8$ & $<8$ \\
\hline 12 & 64 & $<8$ & & - & - & - \\
\hline 13 & 2000 & $<8$ & 128 & 2000 & 512 & 512 \\
\hline 14 & 64 & $<8$ & & - & - & - \\
\hline 15 & 512 & $<8$ & 64 & 512 & 128 & 128 \\
\hline 16 & 64 & $<8$ & - & 64 & 32 & 32 \\
\hline 17 & 2000 & $<8$ & 512 & - & - & $\ldots$ \\
\hline 18 & 64 & $<8$ & 8 & 32 & 32 & 32 \\
\hline Positive control & 512 & 512 & 512 & $<8$ & $<8$ & $<8$ \\
\hline Negative control & $<8$ & $<8$ & $<8$ & $<8$ & $<8$ & $<8$ \\
\hline
\end{tabular}

absorption against toxoplasma trophozoites are shown in table 3. Dilution in BSA did not change the latex agglutination test reactivity of control sera but reduced that of all test sera except that of case 5 . Absorption against toxoplasma trophozoites consistently abolished the reactivity of control sera but only reduced that of the test samples.

None of the samples showed evidence of acute CMV or EBV infection. Antinuclear factor was demonstrable in four sera and rheumatoid factor in two samples. Hepatitis B virus " $e$ " antigen was not found in any of the samples. All 12 sera subjected to prolonged heat inactivation produced latex agglutination test titres of $<16$ throughout. Serum from case 3 alone was reactive to uncoated latex particles.

\section{Discussion}

The latex agglutination test has been shown to be an adequate screening test for toxoplasmosis ${ }^{7}$ but not to be suitable as a substitute for the dye test. ${ }^{8}$ Latex agglutination test titres are not directly comparable with those of the dye test but the separation of negative from positive samples is satisfactory. In our experience, two serum samples containing toxoplasma antibody would have been missed out of the $\mathbf{4 4 5 0}$ tested using a properly performed latex agglutination test as a screen. Interestingly, these two samples were both fetal sera taken in instances of suspected congenital infection. Samples taken from patients at risk of severe toxoplasma infection (a fetus, those with malignancy, HIV infection, or transplant recipients) should be considered for referral to a reference laboratory, irrespective of screening test results.

The numbers of sera reacting in the latex agglutina- tion test but not the dye test were relatively small (1$2 \%$ of the sera tested). The dye test is a highly specific and sensitive assay for the detection of toxoplasma infection. ${ }^{9}$ Only two of 18 sera contained antibody detectable by the dye test, however, even when performed using neat sera rather than the usual screening dilution of $1 / 4$. Most discrepant latex agglutination test/dye test results are not due to a difference in sensitivity between the two tests. Neither do these apparently "false positive" latex agglutination reactions represent kit batch variation. Seventeen of the 18 sera giving discrepant latex agglutination test results failed to react when tested by the direct agglutination assay. The performance of the current direct agglutination test entails treatment of the sera with mercaptoethanol of the sera, this removing IgM antibody. A detailed assessment of this test is in progress at our laboratory. Desmonts et al showed that most sera of adults and children over the age of 3 months contained "natural" IgM antibodies that produced a low titre reaction in the original direct agglutination assay. ${ }^{10}$ These natural antibodies are present in sera from almost all people over the age of 6 months but we have shown discrepant latex reactions in less than $2 \%$ of the serum samples tested.

The aetiology of discrepant latex reaction has been considered by other workers. One Japanese group reported that sera containing a high concentration of hepatitis B virus " $e$ " antigen gave false positive reactions with the latex agglutination test." They attributed these results to a cross-reaction between serum albumin used in the preparation of the coated latex particles and the "e" antigen. Such reactions were unaffected by treatment with 2-mercaptoethanol of the sera. A second Japanese group found that 
certain sera gave low positive latex agglutination test results due to non-toxoplasma-specific IgM antibodies. ${ }^{12}$ These IgM antibodies were seen to bind to the polar region of the toxoplasma tachyzoite. Wreghitt and co-workers described the appearance of false positive latex agglutination test reactions in sera taken from recipients of heart transplants. ${ }^{2}$ They confirmed that these reactions were associated with the IgM fraction and found an association with CMV infection. In their patients this antibody was not CMV specific, nor positive for Paul Bunnell antibody or rheumatoid factor. Our findings support the view that discrepant latex reactions are neither associated with these factors nor antinuclear factor. We were unable to show concurrent CMV infection in our patients, who were not restricted to organ transplant recipients. The IgM antibody in these reactions may be associated with albumin and toxoplasma antigens but is not specific to these antigens. Occasional serum samples may give a positive latex agglutination test result due to antibodies reacting to latex, as in case 3 . It has been shown that heating serum can induce false positive toxoplasma serological results when tested by ELISA. $^{14}$ This phenomenon has not been reported in association with the latex agglutination test and could not be shown using excessive inactivation of sera.

The results of case 5 are of particular interest. The latex agglutination reaction was found to be resistant to mercaptoethanol treatment of the serum and accompanied by a positive direct agglutination assay despite a negative dye test result. Such a combination of results may be seen when the immune system fails to recognise toxoplasma membrane antigens and reacts exclusively to antigens of the cytoplasm. Alternatively, antibody binding to the toxoplasma membrane but failing to fix complement would result in a negative dye test reaction. Further studies of this case are in hand.

The latex agglutination test is a useful screening assay in cases of suspected toxoplasmosis but false positive reactions occur due to an unspecified IgM antibody. False negative latex agglutination test results are uncommon but the serological investigation of groups at risk of severe toxoplasmosis should include additional tests. Exceptionally, discrepancy between dye test and latex agglutination test findings may suggest a false negative dye test result and may require extensive investigation.

We thank BS Chessum and Dr DG Fleck for their advice throughout the course of this study and Mrs I Crossman for her secretarial assistance.

\section{References}

1 Sabin AB, Feldman HA. Dyes as microchemical indicators of a new immunity phenomenon affecting a protozoan parasite. Science 1948;108:660-3.

2 Wreghitt TG, Gray JJ, Balfour AH. Problems with the serological diagnosis of Toxoplasma gondii infections in heart transplant recipients. J Clin Pathol 1986;39:1135-9.

3 Fleck DG, Kwantes W. The laboratory diagnosis of toxoplasmosis. Public Health Laboratory Service Monograph 13. London: HMSO, 1980:5-7.

4 Payne RA, Isaac M, Francis JM. Enzyme-linked immunosorbent assay (ELISA) using antibody class capture for the detection of antitoxoplasma IgM. J Clin Pathol 1982;35:892-6.

5 Kangro HO, Booth JC, Bakir TM, Tryhorn Y, Sutherland S. Detection of IgM antibodies against cytomegalovirus. J Med Virol 1984;14:73-80.

6 Booth JC, Hannington G, Tryhorn Y, Stern H. Cytomegalovirus complement-fixing IgM antibody. J Med Virol 1980;5:183-93.

7 Balfour AH, Fleck DG, Hughes HPA, Sharp D. Comparative study of three tests (dye test, indirect haemagglutination test, latex agglutination test) for the detection of antibodies to Toxoplasma gondii in human sera. J Clin Pathol 1982;35: 228-32.

8 Payne RA, Francis JM, Kwantes W. Comparison of a latex agglutination test with other serological tests for the measurement of antibodies to Toxoplasma gondii. J Clin Pathol 1984;37:1293-7.

9 Sousa OE, Saenz RE, Frenkel JK. Toxoplasmosis in Panama: A 10-year study. Am J Trop Med Hyg 1988;38:315-22.

10 Desmonts G, Baufine-Ducrocq H, Couzinequ P, Peloux Y. Anticorps toxoplasmic naturels. Nouv Presse Med 1974;3: $1547-9$.

11 Ise Y, lida T, Sato K, Suzuki T, Shimada K. Studies on non specific reactions in the toxoplasma latex agglutination test. $J p n J$ Parasitol 1981;30:579-85.

12 Oshima T, Ando K, Suzuki H, et al. False positive reactions due to non-specific IgM in the toxoplasma indirect latex agglutinaton test. Igaku-no-Ayumi 1982;121:485-7.

13 Francis JM, Payne RA, Joynson DHM, Balfour AH. False positive results with heated sera in toxoplasma ELISA for IgG antibody. J Clin Pathol 1987;40:356.

Requests for reprints to Dr R E Holliman, Public Health Laboratory Service, Toxoplasma Reference Laboratory, St George's Hospital, London SW17 0QT, England. 